\title{
Formulasi Fruit Bars Berbasis Tepung Pisang Ditinjau dari Karakteristik Fisik, Kimia dan Organoleptik
}

\author{
Adryananda Nekstaria ${ }^{\text {a,1*}}$, Zidan Arief Fardhani ${ }^{\text {b,2 }}$, Ahmad Syifa'ul Qulub ${ }^{\text {b,3 }}$, Iffah \\ Muflihati ${ }^{\mathrm{b}, 4}$ \\ a, Universitas PGRI Semarang, Jl. Sidodadi Timur, Dr. Cipto Semarang, 8316377 \\ ${ }^{\mathrm{b}}$ Universitas PGRI Semarang, Jl. Sidodadi Timur, Dr. Cipto Semarang, 8316377 \\ 1 e-mail: adryanandanekstaria14@gmail.com \\ * penulis korespondensi
}

\begin{abstract}
They aim of this study was to determine the formulation, chemical and organoleptic characteristics of fruit bars made from Kepok, Raja and Susu banana flour with the addition of soy flour. The study used a completely randomized design with one factor, namely the use of basic ingredients of Kepok, Raja, and Susu banana flour. The results showed that the fruit bars of the three types of bananas had water content and fiber content that were not significantly different, whereas the yield of dough and organoleptic tests showed significantly different results. The highest yield of the dough in the treatment of fruit bars using the basic ingredients of milk flour is $0.88 \mathrm{~g}$. The organoleptic test of fruit bars that can be accepted by panelists is the treatment of fruit bars using the ingredients of Kepok banana.
\end{abstract}

Keywords: fruit bars, kepok banana, raja banana, susu banana

ABSTRAK

Penelitian ini bertujuan untuk mengetahui formulasi serta karakteristik fisik, kimia dan organoleptik fruit bars berbahan dasar tepung buah pisang kepok, raja dan susu dengan penambahan tepung kedelai. Penelitian menggunakan rancangan acak lengkap dengan satu faktor yaitu penggunaan bahan dasar tepung pisang kepok, tepung pisang raja dan tepung pisang susu. Hasil penelitian menunjukkan bahwa fruit bars dari ketiga jenis pisang memiliki kadar air dan kadar serat yang tidak berbeda nyata, sedangkan pada rendemen adonan dan uji organoleptik menunjukkan hasil berbeda nyata. Rendemen adonan tertinggi pada perlakuan fruit bars dengan menggunakan bahan dasar tepung susu yaitu $0,88 \mathrm{~g}$ dan uji organoleptik fruit bars yang dapat diterima panelis adalah pada perlakuan fruit bars menggunakan bahan dasar pisang kepok.

Kata Kunci: fruit bars, pisang kepok, pisang raja, pisang susu

\section{Pendahuluan}

Kemajuan teknologi pangan telah menghasilkan berbagai produk makanan yang praktis dikonsumsi, masyarakat mulai menyadari akan pentingnya kesehatan namun di sisi lain kesibukan masyarakat semakin meningkat sehingga kebutuhan pangan tidak sebatas pada pemenuhan gizi dan cita rasa yang enak melainkan produk pangan juga diharapkan mampu menyehatkan, aman dikonsumsi serta praktis dalam penyajiannya. Salah satu produk pangan yang aman, menyehatkan dan praktis adalah food bars. Kebanyakan food bars terbuat dari tepung terigu yang menyebabkan impor gandum terus meningkat. 
Di sisi lain, sudah banyak dikembangkan food bars dari tepung kacang-kacangan seperti food bars dari tepung kacang dan tepung kedelai (Agung et al., 2017), tepung kedelai dan tepung kacang hijau (Fajri et al., 2013), tepung millet putih dan tepung kacang merah (Baskara et al., 2016).

Penggunaan tepung kacang-kacangan pada umumnya akan menimbulkan bau dan rasa langu yang tidak disukai konsumen. Semakin sedikit jumlah penggunaan tepung kacang maka semakin tinggi tingkat kesukaan konsumen terhadap rasa food bars. Pengguaan tepung buah dapat menutupi bau dan rasa langu dari food bars. Pisang merupakan salah satu komoditas nasional yang memiliki kandungan gizi yang cukup tinggi dan lengkap. Kandungan gizi pisang terdiri dari karbohidrat, protein, lemak, air dan vitamin A, B1, B2 dan C. Pisang pada umumnya dikonsumsi dalam bentuk segar, salah satu upaya untuk memberikan nilai tambah dari komoditas pisang adalah dengan mengolah pisang menjadi berbagai produk olahan siap saji dengan nilai kalori yang mencukupi kebutuhan tubuh yaitu food bars. Penggunaan tepung pisang sebagai bahan baku food bars selain mampu meningkatkan nilai gizi food bars terutama pada kadar seratnya, tepung pisang juga diharapkan mampu menutupi bau dan rasa langu pada food bars yang terbuat dari tepung kacang-kacangan.

\section{Metode Penelitian}

\subsection{Bahan dan Alat}

Bahan yang digunakan dalam penelitian ini adalah 15 gram tepung pisang raja, tepung pisang kepok, tepung pisang susu, 10 gram tepung kedelai, kismis dan cranbery secukupnya, 13 gram susu bubuk full cream, 2 gram gula dan 10 gram margarin. Alat yang digunakan dalam penelitian ini adalah cabinet dryer, mixer, wadah adonan, loyang, spatula, blender kering dan oven.

\subsection{Pembuatan Tepung Pisang dan Tepung Kedelai}

Pisang dikupas dan dipotong tipis-tipis kemudian diletakkan pada loyang yang sudah beralaskan kertas roti anti lengket dan dikeringkan menggunakan cabinet dryer. Pisang kering kemudian dihaluskan menggunakan blender kering, lalu diayak menggunakan ayakan 60 mesh. Didapatkan tepung buah pisang. Selanjutnya untuk pembuatan tepung kedelai diawali dengan perebusan kedelai selama 15 menit kemudian direndam selama 4 jam. Kedelai dikeringkan di cabinet dryer dan dihaluskan menggunakan blender kering, bubuk kedelai kemudian diayak menggunakan ayakan 60 mesh.

\subsection{Pembuatan Fruit Bars}

Pembuatan food bars diawali dengan pencampuran tepung pisang, tepung kedelai, susu bubuk full cream, gula, margarin, menggunakan mixer hingga homogen, setelah itu dicampur buah kering tanpa menggunakan mixer. Adonan kemudian dicetak dan diolesi menggunakan kuning telur untuk kemudian ditaburkan oat pada bagian permukaan food bars. Adonan food bars selanjutnya di panggang dalam oven yang telah diatur suhunya $120^{\circ} \mathrm{C}$ selama 40 menit. Selanjutnya dilakukan pendinginan dengan membiarkan food bars yang telah dikeluarkan dari oven pada suhu kamar beberapa menit. 


\subsection{Formulasi Fruit Bars}

Formulasi fruit bars dapat dilihat pada Tabel 2.1.

Tabel 2.1. Formulasi Fruit Bars

\begin{tabular}{cc}
\hline Bahan & Jumlah bahan $(\mathrm{g})$ \\
\hline Tepung pisang & 15 \\
Tepung kedelai & 10 \\
Susu bubuk full cream & 13 \\
Gula & 2 \\
Margarin & 10 \\
\hline
\end{tabular}

\subsection{Rancangan Penelitian}

Rancangan penelitian yang digunakan adalah Rancangan Acak Lengkap (RAL) dengan satu faktor yaitu varietas pisang (Pisang raja, pisang kepok dan pisang susu). Pengolahan data penelitian dilakukan secara statistik dengan uji ANOVA (Analysis Of Variance).

\subsection{Metode Analisis}

Analisis fisik yang diuji yaitu kadar air (AOAC, 2005) dan rendemen adonan, analisis kimia yang diuji yaitu kadar serat kasar (AOAC, 2005). Analisis sensori yang diuji yaitu hedonik dan uji deskriptif. Uji hedonik menggunakan panelis tidak terlatih sebanyak 25 orang dengan parameter aroma, flavor, tekstur dan keseluruhan, skala penilaian uji hedonik dari 1 hingga 5 (dari sangat tidak suka hingga sangat suka). Uji deskriptif menggunakan panelis tidak terlatih sebanyak 15 orang dengan parameter aroma, flavor yang memiliki skala penilaian dari 1 hingga 5 (dari sangat tidak kuat hingga sangat kuat) dan tekstur kekerasan dengan skala penilaian dari 1 hingga 5 (dari sangat tidak keras hingga sangat keras).

\section{Hasil dan Pembahasan}

\subsection{Kadar Air Fruit Bars}

Analisis kadar air merupakan analisis yang dilakukan untuk menentukan kadar air di dalam suatu bahan pangan dan dinyatakan dalam persen. Kadar air di dalam bahan pangan dapat ditentukan dengan cara analisis kadar air metode oven (AOAC, 2005). Kadar air dalam suatu bahan pangan mempengaruhi penampakan, tekstur, cita rasa, dan keawetan bahan pangan (Ridla, 2014). Analisis kadar air dapat dilihat pada Gambar 3.1.

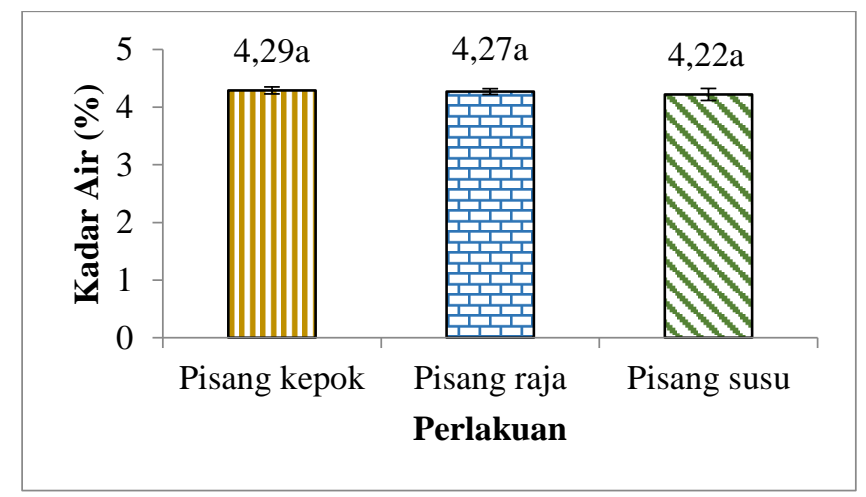

Gambar 3.1. Kadar Air Fruit Bars 
Kadar air fruit bars pisang kepok, pisang raja dan pisang susu tidak berbeda nyata. Kandungan air dalam bahan pangan dapat mempengaruhi laju kerusakan oleh proses kimiawi, enzimatis dan mikrobiologis. Nilai kadar air dari fruit bar sangat dipengaruhi oleh bahan yang digunakan seperti jumlah air yang ditambahkan dan juga tingkat kematangan pisang. Tepung-tepungan yang digunakan memiliki kadar air $<10 \%$. Kadar air ini tergolong aman untuk disimpan. Menurut Winarno (2008) kadar air bahan pangan yang aman untuk penyimpanan adalah kurang dari 14\%. Food bars belum memiliki SNI kadar air sehingga belum bisa dipastikan berapa kadar air yang seharusnya dalam produk food bars.

Salah satu syarat food bars agar dapat dijadikan sebagai pangan darurat adalah harus memiliki kadar air yang rendah agar dapat disimpan dalam jangka waktu yang lama. Kandungan air memiliki pengaruh terhadap daya simpan makanan, kadar air erat kaitannya dengan pertumbuhan mikroba atau jamur. Semakin rendah kandungan air pada bahan makanan maka akan lebih lama penyimpananya (Almasyhuri et al., 2012). Kadar air yang rendah pada food bars disebakan karena bahan dasar food bars sudah dalam bentuk kering dan telah mengalami pengeringan terlebih dahulu. Pemanggangan merupakan salah satu faktor dari kadar air yang rendah pada food bars. Ekafitri dan Isworo (2014), menyatakan tujuan dari pemanggangan adalah menghancurkan mikroorganisme dan pengurangan aktivitas air pada bahan pangan.

\subsection{Rendemen Adonan}

Rendemen adonan dapat dilihat pada Gambar 3.2.

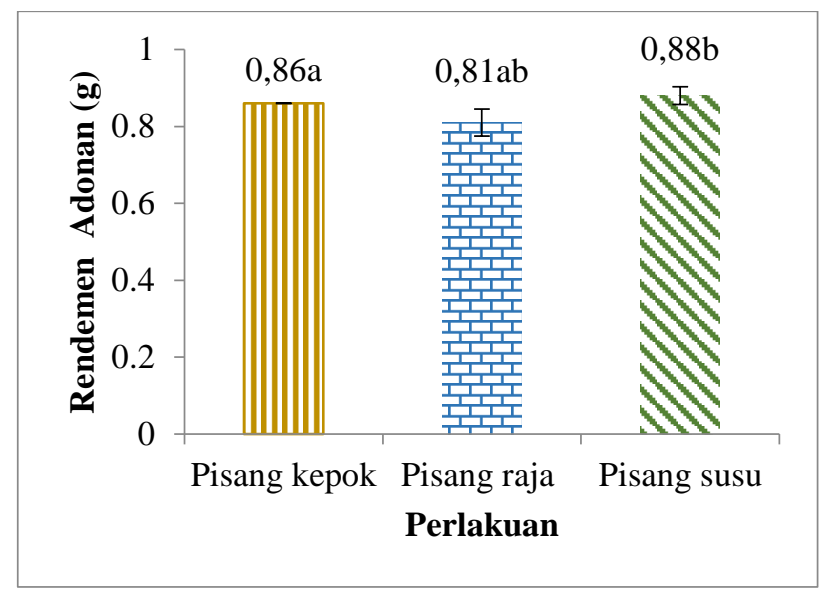

Gambar 3.2. Rendemen Adonan Fruit Bar

Rendemen adonan pisang raja berbeda nyata dengan pisang kepok dan pisang susu, pisang kepok berbeda nyata dengan pisang susu. Rendemen tertinggi dihasilkan pada penggunaan tepung susu dan rendemen terendah dihasilkan pada penggunaan tepung pisang raja. Hal ini dikarenakan kandungan protein pisang susu yang lebih tinggi dibandingkan dengan pisang raja. Menurut Nio (2012), pisang susu memiliki kandungan protein 1,2 g per 100 gram. Menurut Riana (2000), pisang raja memiliki kandungan protein sebesar $0,2 \mathrm{~g}$ per 100 gram.

Protein merupakan senyawa yang cukup berpengaruh besar terhadap kualitas produk yang dihasilkan, kemampuan produk fruit bars untuk menahan stabilitas adonan pada saat proses pembuatan (Hildayanti, 2012). Protein merupakan salah satu komponen yang berpengaruh terhadap daya serap suatu bahan. Hal yang berpengaruh terhadap interaksi 
protein - air adalah gugus amino polar yang terdapat dalam protein, seperti karbonil, hidroksil, dan sulfihidril. Sisi kationik, anionik dan non ionik menyerap air dalam jumlah yang berbeda (Fardiaz et al., 1992)

Daya serap air menunjukan kemampuan bahan untuk dapat berinteraksi dengan air. Interaksi protein dengan air menentukan sifat hidrasi, pengembangan produk dan visikositas. Selain sifat protein, daya serap air bahan juga dipengaruhi oleh keberadaan dan jumlah gugus polar dan non polar dalam bahan. Protein menjadi penting sebagai komponen yang menentukan tingkat penyerapan air karena hampir semua protein mengandung jumlah rantai polar sepanjang kerangka peptidanya dan membuatnya bersifat hidrofilik (Cherry, 1981).

\subsection{Kadar Serat Kasar}

Kadar serat kasar dapat dilihat pada Tabel 3.1.

Tabel 3.1. Kadar Serat Fruit Bars

\begin{tabular}{lc}
\hline \multicolumn{1}{c}{ Jenis pisang } & Kadar serat kasar \\
\hline Pisang susu & $0,28 \pm 0,035^{\mathrm{a}}$ \\
Pisang kepok & $0,26 \pm 0,021^{\mathrm{a}}$ \\
Pisang raja & $0,26 \pm 0,021^{\mathrm{a}}$ \\
\hline
\end{tabular}

Serat kasar adalah bagian dari karbohidrat yang tidak dapat dihidrolisis oleh asam dan basa kuat yaitu $\mathrm{H}_{2} \mathrm{SO}_{4}$ dan $\mathrm{NaOH}$. Dibandingkan enzim pencernaan, $\mathrm{H}_{2} \mathrm{SO}_{4}$ dan $\mathrm{NaOH}$ mempunyai kemampuan yang lebih besar dalam menghidrolisis komponen makanan hal tersebut menyebabkan nilai serat kasar lebih rendah dinbandingkan dengan serat makanan. Serat tidak dapat diubah menjadi energi oleh tubuh manusia tetapi sangat berperan dalam proses pencernaan (Putra, 2013). Serat kasar adalah serat tumbuhan yang tidak larut dalam air, kadar serat kasar dalam suatu bahan makanan dapat dijadikan indeks kadar serat makanan karena umumnya didalam serat kasar ditemukan $0.2-0.5$ bagian jumlah serat makanan (Winarno 2002). Kadar serat kasar fruit bars tidak berbeda nyata pada ketiga jenis fruit bars, kadar serat kasar dapat dipengaruhi oleh perbedaan kandungan serat kasar bahan baku yang digunakan. Kadar serat kasar tepung pisang pada umumnya sekitar 1,96-2,51\%, oat juga menyumbang kadar serat kasar dalam fruit bars semakin tinggi konsentrasi oat yang digunakan maka kadar serat kasar akan semakin meningkat.

\subsection{Uji Hedonik Fruit Bars}

Uji hedonik fruit bars dapat dilihat pada Tabel 3.2.

Tabel 3.2. Uji Hedonik Fruit Bars

\begin{tabular}{ccccc}
\hline \multirow{2}{*}{ Jenis Pisang } & \multicolumn{4}{c}{ Parameter } \\
\cline { 2 - 5 } & Aroma & Rasa & Tekstur & Keseluruhan \\
\hline Pisang Raja & $3,44 \pm 0,92^{\mathrm{a}}$ & $3,04 \pm 0,68^{\mathrm{a}}$ & $3,2 \pm 0,91^{\mathrm{a}}$ & $3,24 \pm 0,60^{\mathrm{a}}$ \\
Pisang Kepok & $3,92 \pm 0,64^{\mathrm{b}}$ & $3,88 \pm 0,72^{\mathrm{b}}$ & $3,76 \pm 0,83^{\mathrm{b}}$ & $3,96 \pm 0,61^{\mathrm{b}}$ \\
Pisang Susu & $3,48 \pm 0,77^{\mathrm{ab}}$ & $3,24 \pm 0,78^{\mathrm{a}}$ & $3,04 \pm 0,84^{\mathrm{a}}$ & $3,28 \pm 0,68^{\mathrm{a}}$ \\
\hline
\end{tabular}


Aroma fruit bars dari tepung pisang susu berbeda nyata dengan fruit bars dari bahan dasar tepung pisang raja dan pisang kepok. Fruit bars tepung pisang kepok berbeda nyata dengan fruit bars pisang raja. Aroma yang paling disukai adalah fruit bars tepung pisang susu, hal ini disebabkan perbedaan kematangan dari buah pisang. Menurut Ferawati (2009), komponen volatil pisang matang relatif tinggi kelengkapannya dan sebagian besar terdiri atas campuran kompleks ester-ester, alkohol, aldehid, keton dan senyawa aromatik. Flavor fruit bars berbasis tepung pisang tidak berbeda nyata baik dari tepung pisang raja, pisang kepok maupun pisang susu. Flavor pisang ditentukan oleh ester amil dan isoamil dari asam asetat, propionat dan butirat, sedangkan alkohol dari karbonil memberi bau yang menggambarkan "woody" atau "musty" dan "green".

Uji kesukaan tekstur fruit bars pisang kepok berbeda nyata dengan fruit bars pisang susu dan fruit bar pisang raja. Tekstur fruit bars pisang kepok lebih disukai oleh panelis dibandingkan fruit bars pisang susu dan fruit bar pisang raja. Fruit bars pisang kepok memiliki tekstur yang lebih lunak dibandingkan fruit bars lainnya sehingga fruit bars tersebut lebih disukai oleh panelis. Tekstur fruit bars dapat dipengaruhi oleh kadar air, kadar air buah pisang ini dipengaruhi oleh tingkat kematangan buah, semakin tinggi tingkat kematangan, semakin tinggi kadar air buah pisang. Menurut Nurhayati (2018), semakin banyak pisang yang ditambahkan maka kandungan air dalam fruit bars semakin tinggi dan dapat menyebabkan tekstur fruit bars menjadi lunak.

Keseluruhan fruit bars, fruit bars dengan daya terima paling disukai terhadap parameter keseluruhan yaitu formulasi fruit bars dengan bahan dasar tepung pisang kepok $15 \mathrm{~g}$, tepung kedelai $10 \mathrm{~g}$, susu bubuk full cream $13 \mathrm{~g}$, gula $2 \mathrm{~g}$ dan margarin $10 \mathrm{~g}$, fruit bars pisang kepok memiliki mean 3,96. Fruit bars pisang susu dan pisang raja memiliki daya terima dengan rentang kesukaan yang hampir sama, masing-masing memiliki mean 3,24 dan 3,28.

\subsection{Uji Deskriptif}

Uji deskriptif fruit bars dapat dilihat pada Tabel 3.3. Aroma pisang pada fruit bars tidak berbeda nyata pada ketiga jenis tepung pisang. Menurut Nurfiliyah et al., (2011) buah pisang masak akan mengandung asam butirat, asam palmitat hingga 54,50\%, asam butirat, propianat dan n-hexanal. Menurut Ferawati (2009), komponen volatil pisang matang relatif tinggi kelengkapannya dan sebagian besar terdiri atas campuran kompleks ester-ester, alkohol, aldehida, keton dan senyawa aromatik. Aroma kedelai pada fruit bars tidak berbeda nyata pada ketiga jenis tepung pisang. Aroma kedelai cenderung menunjuk pada bau langu hal ini disebabkan masih adanya enzim lipoksigenase yang secara alamiah memberikan aroma khusus pada kacang-kacangan (Pertiwi et al., 2017). Aroma susu pada ketiga jenis fruit bars tidak berbeda nyata, aroma susu yang muncul dikarenakan penggunaan susu bubuk full cream. Menurut Fatimah (2013), semakin banyak jumlah susu yang ditambahkan maka akan menghasilkan aroma khas susu yang semakin disukai panelis.

Flavor pisang pada ketiga jenis fruit bars tidak berbeda nyata. Flavor pisang ditentukan oleh ester amil dan isoamil dari asam asetat, propionat dan butirat, sedangkan alkohol dari karbonil memberi bau yang menggambarkan "woody" atau "musty" dan "green". Flavor kedelai pada ketiga jenis fruit bar tidak berbeda nyata. Flavor kedelai cenderung menunjukkan flavor langu, hal ini disebabkan oleh aktivitas enzim 
lipoksigenase. Flavor susu dari ketiga jenis fruit bars tidak berbeda nyata, flavor susu dipengaruhi oleh adanya penggunaan susu bubuk full cream.

Tabel 3.3. Uji Deskriptif Fruit Bars

\begin{tabular}{cccccccc}
\hline \multirow{2}{*}{ Jenis Pisang } & \multicolumn{5}{c}{ Aroma } & \multicolumn{3}{c}{ Rasa } & \multirow{2}{*}{ Tekstur } \\
\cline { 2 - 6 } & \multirow{2}{*}{ Pisang } & \multirow{2}{*}{ Kedelai } & \multirow{2}{*}{ Susu } & $\begin{array}{c}\text { Rasa } \\
\text { Pisang }\end{array}$ & $\begin{array}{c}\text { Rasa } \\
\text { Kedelai }\end{array}$ & Rasa Susu & Kekerasan \\
\hline Pisang Raja & $2,4 \pm 0,99^{\mathrm{a}}$ & $2,6 \pm 0,83^{\mathrm{a}}$ & $2,73 \pm 0,70^{\mathrm{a}}$ & $2,33 \pm 0,90^{\mathrm{a}}$ & $2,67 \pm 0,90^{\mathrm{a}}$ & $2,33 \pm 0,72^{\mathrm{a}}$ & $2,33 \pm 0,62^{\mathrm{a}}$ \\
Pisang Kepok & $2,67 \pm 0,82^{\mathrm{a}}$ & $2,53 \pm 0,83^{\mathrm{a}}$ & $2,8 \pm 0,86^{\mathrm{a}}$ & $2,87 \pm 1,12^{\mathrm{a}}$ & $2,33 \pm 0,82^{\mathrm{a}}$ & $2,87 \pm 1,00^{\mathrm{a}}$ & $1,87 \pm 0,64^{\mathrm{ab}}$ \\
Pisang Susu & $2,67 \pm 0,82^{\mathrm{a}}$ & $2,07 \pm 0,80^{\mathrm{a}}$ & $2,87 \pm 0,74^{\mathrm{a}}$ & $2,67 \pm 1,07^{\mathrm{a}}$ & $2,53 \pm 0,83^{\mathrm{a}}$ & $2,8 \pm 1,15^{\mathrm{a}}$ & $2,73 \pm 0,80^{\mathrm{b}}$ \\
\hline
\end{tabular}

Kekerasan adalah besarnya gaya yang diberikan hingga objek mengalami perubahan bentuk. Fruit bars dari tepung pisang kepok berbeda nyata dengan fruit bars pisang raja dan pisang susu. Fruit bars pisang kepok memiliki kekerasan yang lebih rendah dibandingkan dengan fruit bars pisang raja dan pisang susu. Kandungan air pada fruit bars dapat mempengaruhi kekerasan fruit bars. Analisis kadar air yang dilakukan pada fruit bars menunjukkan kadar air fruit bar pisang kepok lebih tinggi dibandingkan dengan fruit bars lainnya yaitu 4,29\%, sehingga menyebabkan tekstur fruit bars pisang kepok lebih lunak dibandingkan dengan fruit bars pisang susu dan fruit bars pisang raja. Menurut Nurhayati (2018), semakin banyak pisang yang ditambahkan maka kandungan air dalam fruit bars semakin tinggi dan dapat menyebabkan tekstur fruit bars menjadi lunak.

\section{Kesimpulan}

Hasil penelitian menunjukkan bahwa fruit bars dari ketiga jenis pisang memiliki kadar air dan kadar serat yang tidak berbeda nyata nilai kadar air dari fruit bars sangat dipengaruhi oleh bahan yang digunakan seperti jumlah air yang ditambahkan dan juga tingkat kematangan pisang dan kadar serat kasar yang dipengaruhi oleh perbedaan kandungan serat kasar bahan baku yang digunakan dan konsentrasi oat yang digunakan, sedangkan pada rendemen adonan dan uji organoleptik menunjukkan hasil berbeda nyata. Rendemen adonan tertinggi pada perlakuan fruit bars dengan menggunakan bahan dasar tepung susu yaitu $0,88 \mathrm{~g}$ dan uji organoleptik fruit bars yang dapat diterima panelis adalah pada perlakuan fruit bars menggunakan bahan dasar pisang kepok. Fruit bars berbahan dasar pisang kepok memiliki rasa khas pisang yang tinggi, rasa kedelai yang rendah dan tekstur yang tidak terlalu keras.

\section{Pustaka}

Agung, dkk. 2017. "Formulasi dan Karakteristik Nutrimat Bar Berbasis Tepung Kacang Kedelai (Glycine max. L) dan Tepung Kacang Merah (Phaseolus vulgaris. L) sebagai makanan pasien kemoterapi”, dalam Jurnal Gizi Indonesia. Vol. 5, No. 2 : 133-139. 
Almasyhuri. 2012. "Formulasi Biskuit Padat Siap-Santap Untuk Makanan Darurat", dalam Penel Gizi Makan. Vol. 35, No. 1: 42-48.

Baskar, dkk. 2016. "Formulasi Pangan Darurat Berbentuk Food Bars Berbasis Tepung Millet Putih (Panicum milliaceum L.) dan Tepung Kacang Merah (Phaseolus vulgaris L.)", dalam Journal Agritech. Vol. 36, No. 1: 23-29.

Cherry, J.P. and K.H. McWaters. 1981. Whippability and Aeration. In: J.P. Cherry. Protein Functionality in Foods. American Chemical Society. Washington D.C.

Ekafitri, R., \& Isworo, R. (2014). "Pemanfaatan Kacang-Kacangan sebagai Bahan Baku Sumber Protein Untuk Pangan Darurat", dalam Jurnal Pangan. Vol. 23, No. 2: 134-144.

Fajri, dkk. 2013. "Karakteristik Fisikokimia dan Organoleptik Food Bars Labu Kuning (Cucurbita máxima) Dengan Penambahan Tepung Kedelai dan Tepung Kacang Hijau Sebagai Alternatif Produk Pangan Darurat", dalam Jurnal Teknologi Hasil Pertanian. Vol. 6, No. 2: 103-110.

Fardiaz, S. 1992. Mikrobiologi Pengolahan Pangun Lanjut. Bogor: PAU Pangan dan Gizi Institut Pertanian Bogor.

Fatimah, P. S., E. Nasution, dan E. Y. Aritonang. 2013. "Uji Daya Terima dan Nilai Gizi Biskuit yang Dimodifikasi dengan Tepung Kacang Merah", dalam Jurnal kesehatan Masyarakat. Vol. 2, No. 6: 1-7.

Ferawati. 2009. Formulasi dan Pembuatan Banana Bars Berbahan Dasar Tepung Kedelai, Terigu, Singkong dan Pisang Sebagai Alternatif Pangan Darurat. Bogor: ITB.

Hildayanti. 2012. Studi Pembuatan Flakes Jejawut (Setaria italica). Skripsi Jurusan Teknologi Pertanian. Fakultas Pertanian. Universitas Hasanudin Makasar.

Nio, Oey kam. 1992. Daftar Analisis Bahan Makanan. Jakarta: Balai Penerbit FKUI. Nurfiliyah, S.A., dan Widjarnarko, S.B. 2014. "Uji Efektifitas Pelepasan Retronasal Aroma Jeli Pisang Ambon Putih Terhadap Persepsi Kenyang Panelis Overweight dan Obesitas", dalam Jurnal Pangan dan Agroindustri. Vol. 2, No. 2: 9-15.

Nurhayati, dkk. 2018. "Formulasi Food Bars Berbasis Tepung Ubi Jalar Ungu dan Pisang Agung (Musa paradisiaca formatypica) Masak", dalam Jurnal Agroteknologi. Vol. 12, No. 1: 71-78.

Pertiwi, A. D., Widanti, Y. A., \& Mustofa, A. 2017. "Substitusi Tepung Kacang Merah (Phaseolus vulgaris L.) pada Mie Kering dengan Penambahan Ekstrak Bit (Beta vulgaris L.)", dalam Jurnal Teknologi dan Industri Pangan. Vol. 2, No. 1: 67-73. Putra, SR. 2013. Pengantar Ilmu Gizi dan Diet. D-Medika. Yogyakarta. Ridla, M. 2014. Pengenalan Bahan Makanan. Bogor: Institusi Pertanian Bogor. Winarno FG. 2008. Kimia Pangan. Jakarta: PT. Gramedia Pustaka Utama. 